\title{
Pola Komunikasi Penyanyi Dangdut, Konflik, dan Resolusi Penyelesaiannya (Studi pada Penyanyi Dangdut di Desa Banjarsawah, Kecamatan Tegalsiwalan, Kabupaten Probolinggo)
}

\author{
Sajidah Muhabbatillah ${ }^{1 *}$, Tri Gunawan ${ }^{2}$ \\ ${ }^{1,2}$ Jurusan Sosiologi, Universitas Negeri Malang \\ *muhabbatillahsajidah@gmail.com
}

\begin{abstract}
Being a dangdut singer is not an easy profession. There are still many negative assumptions from the community towards this profession. Even so, there are still many women who become dangdut singers, although often criticized. As happened in the village of Banjarsawah, Tegalsiwalan District, Probolinggo Regency. This study seeks to describe the communication carried out by dangdut singers and the audience so that they are liked a lot, the conflicts experienced by dangdut singers, and the treatment of conflicts and communication efforts in the resolution process. This study uses descriptive qualitative method. The results showed that the dangdut singer tried to establish good communication with the audience by always greeting and asking the songs you want to listen to. Conflicts often occur between dangdut singers and with their neighborhoods. The settlement process is done by ignoring the negative assumptions given by the community, improving communication, and avoiding the community that is acting badtowards them.
\end{abstract}

Keywords: Communication, Conflict, Dangdut Singer, Resolution

\begin{abstract}
Abstrak
Menjadi penyanyi dangdut bukanlah profesi yang mudah. Masih banyak anggapan negatif dari masyarakat terhadap profesi ini. Meskipun begitu, masih banyak perempuan yang menjadi penyanyi dangdut walaupun seringkali mendapat kecaman. Seperti yang terjadi di Desa Banjarsawah, Kecamatan Tegalsiwalan, Kabupaten Probolinggo. Penelitian ini berusaha untuk mendeskripsikan komunikasi yang dilakukan penyanyi dangdut dengan penonton agar banyak disukai, konflik yang dialami oleh penyanyi dangdut, dan perlakuan konflik serta upaya komunikasi dalam proses resolusinya. Penelitian ini menggunakan metode penelitian kualitatif deskriptif. Hasil penelitian menunjukkan bahwa penyanyi dangdut berusaha untuk menjalin komunikasi yang baik dengan penonton dengan cara selalu menyapa dan menanyakan lagu yang ingin didengarkan. Konflik sering terjadi baik antar penyanyi dangdut maupun dengan lingkungan tempat tinggal mereka. Proses penyelesaian yang dilakukan adalah dengan jalan mengabaikan anggapan negatif yang diberikan masyarakat, memperbaiki komunikasi, dan menghindari masyarakat yang berlaku buruk terhadap mereka.
\end{abstract}

Kata Kunci: Komunikasi, Konflik, Penyanyi Dangdut, Resolusi

\section{Pendahuluan}

Salah satu sarana hiburan bagi masyarakat lokal pedesaan adalah adanya musik dangdut. Musik dangdut adalah salah satugenre musik di Indonesia yang merupakanperpaduan antara musik melayu dan India (Sulistyaningtyas \& Suharto, 2017). Mayoritas pelaku hiburan musik dangdut adalah perempuan sebagai penyanyinya dengan diiringi pemukul alat musik yang mayoritas laki-laki. Sehingga, tidak heran apabila kebanyakan penikmat musik dangdut adalah laki-laki mulai dari usia muda hingga tua berkat penyanyi dangdut yang berjenis kelamin perempuan dengan tampilannya yang seksi. Namun, disisi lain banyak anggapan dari masyarakat bahwa penyanyi dangdut perempuan terlalu seksi, sensual, dan murahan dengan polesan make-up 
yang menor sebagai ciri khas pada penampilan mereka dengan tujuan akan semakin mampu menarik minat laki-laki hidung belang untuk datang menonton mereka. Selain penampilan penyanyi dangdut yang menjadi nomor satu, suara juga patut dipertimbangkan agar profesi penyanyi dangdut lebih paripurna.

Anggapan negatif terhadap penyanyi dangdut lokal terjadi di lingkungan keluarga tempat tinggal hingga masyarakat luas. Hal tersebut dapat membentuk konsep diri yang negatif pula melalui komunikasi pribadi penyanyi dangdut yang bersangkutan. Mereka akan menjadi pribadi yang minder dan kurang yakin dalam menyelesaikan permasalahan yang dihadapinya. Selain komunikasi dalam diri pribadi, kecakapan komunikasi dengan orang lain juga menjadi penentu bagaimana hubungan baik dapat terjalin antar sesama masyarakat manusia sehingga keharmonisan di dalam keluarga bisa terjalin. Berbeda halnya ketika komunikasi antar diri pribadi dan dengan pribadi yang lain kurang baik terjalin, maka keharmonisan di dalam keluarga dan hubungan sosial juga terhambat.

Fenomena semacam itu terjadi di Desa Banjarsawah Kecamatan Tegalsiwalan Kabupaten Probolinggo. Banyak remaja di desa ini terutama perempuan yang bekerja sebagai penyanyi dangdut dan pemandu lagu pada tempat-tempat karaoke. Menjadi penyanyi dangdut atau pemandu lagu bukanlah pilihan utama karena apabila dilihat dari jumlah bayaran yang didapatkan hanya sedikit. Sebagaian besar bayaran yang didapat oleh penyanyi dangdut dan pemandu lagu adalah berasal dari saweran yang diberikan oleh orang-orang yang datang. Sehingga, seringkali para penyanyi dangdut berpenampilan yang sangat seksi agar orang-orang yang datang semakin tertarik dan memberikan banyak saweran. Begitulah kehidupan penyanyi dangdut dengan gemerlapnya yang selalu menyajikan deretan cerita menarik. Mulai dari goyangan pinggul sang biduan hingga sawean yang bak menjadi tradisi di setiap daerah. Tak heran apabila keseksian penyanyi dangdut mampu menyedot ribuan penonton, khususnya kaum laki-laki.

Hasil penelitian terdahulu oleh Selamet Hariyono (2011) dalam penelitian yang berjudul "Dangdut dan Eksploitasi Seks Perempuan". Dari penelitian Selamet Hariyono ini membahas tentang penyanyi dangdut hanya sebagai sosok perempuan seksi yang sedang bernyanyi sambil menari-nari di atas pentas dengan goyangan yang erotisnya dan adanya penonton yang bergoyang secara masal yang melakukannya secara histeris mengikuti irama lagu yang sedang didengarkannya, selain itu penelitian yang dilakukan oleh Selamet Hariyono ini membahas keseksian penyanyi dangdut sehingga terjadinya eksploitasi sek perempuan dalam pertunjukan musik dangdut dengan menggunakan pendekatan estetika feminisme(Haryono, 2002).

Dalam penelitian tentang penyanyi dangdut juga dilakukan oleh Fitriya, Alvi (2017) dalam penelitian yang berjudul "Hubungan Kuasa Komunikasi Panggung Penyanyi Dangdut". Dari penelitian tersebut membahas tentang bahwa penyanyi dangdut identik memiliki kecenderungan korban pemerkosaan dengan melalui bujukan tawaran job menyanyi. Disini penyanyi dangdut hanya sebagai penjualkeseksian semata sehinggatidak mempedulikan kualitas suara yang mereka miliki. Selain itu dalam penelitian Fitriya juga membahas tentang Power Relations yang merupakan sebagai bentuk kekuatan yang dimiliki agen untuk menciptakan kuasa pada dirinya. (Fitriya\&Dwiningtyas, 2017).

Tulisan ini akan mengulas mengenai tiga sub bab, yaitu komunikasi yang dilakukan penyanyi dangdut dengan penonton, konflik yang dialami oleh penyanyi dangdut, dan perlakuan konflik serta upaya komunikasi dalam proses resolusinya. 


\section{Metodologi}

\subsection{Pendekatan Penelitian}

Penelitian ini menggunakan pendekatan penelitian kualitatif. Moleong menjelaskan bahwa tipe penelitian kualitatif merupakan penelitian yang menggunakan pendekatan naturalistik untuk mencari dan menemukan pengertian atau pemahaman tentang fenomena dalam suatu latar yang berkonteks khusus dan tidak mengadakan perhitungan (Moleong, 2016).

Dalam proses penggalian data dan pengumpulan informasi, peneliti melakukan studi kepustakaan dan turun langsung kelapangan. Saat turun ke lapangan, peneliti melakukan teknik pengamatan secara langsung terhadap penampilan penyanyi dangdut dan kehidupan keseharian mereka. Selain pengamatan tersebut, penulis juga melakukan proses wawancara untuk memperoleh keterangan dari penyanyi dangdut langsung terkait rumusan dan tujuan penelitian dilakukan. Proses wawancara dilakukan dengan bantuan pedoman wawancara dan menggunakan bahasa madura mengingat mayoritas penyanyi dangdut dan penduduk di Desa Banjarsawah merupakan keturunan suku madura.

\subsection{Lokasi dan Waktu Penelitian}

Penelitian ini dilakukan di Desa Banjarsawah Kecamatan Tegalsiwalan Kabupaten Probolinggo. Penulis mengambil lokasi di desa ini karena banyak remaja yang berprofesi sebagai penghibur (penyanyi dangdut dan pemandu lagu) yang notabene masih berstatus pelajar. Penelitian dilaksanakan sekitar bulan pebruari hingga april 2018.

\subsection{Informan Penelitian}

Penelitian ini mengambil informan penelitian sebanyak lima orang penyanyi dangdut yang pernah mengalami konflik atau mendapatkan cemoohan dari warga sekitar, satu orang sebagai petugas penjaga keamanan saat pertunjukan dangdut, dan tiga pemuda yang menggemari pertunjukkan dangdut.

\subsection{Proses Analisis Data}

Proses analisis data di dalam penelitian ini dilakukan dengan mengadopsi metode yang dijelaskan oleh Miles dan Huberman, yakni pengumpulan data, reduksi data, sajian data, dan verifikasi \& penarikan kesimpulan(Ilyas, 2016). Data yang dikumpulkan melalui proses wawancara, observasi, dan dokumentasi direduksi sesuai dengan rumusan masalah dan tujuan penelitian. Setelah proses reduksi selesai, langkah selanjutnya adalah menyajikan data dalam bentuk narasi deskripsi seperti artikel ini. Langkah terakhir adalah menyimpulkan keseluruhan proses pengumpulan data, reduksi data, dan sajian data. Sehingga dari kegiatan tersebut akan didapatkan kesimpulan dari keseluruhan proses penelitian.

\section{Hasildan Pembahasan}

\subsection{Komunikasi Penyanyi Dangdut dengan Penonton}

Pertunjukkan musik dangdut tidak akan lengkap tanpa adanya penonton. Penonton yang datang untuk menyaksikan pertunjukkan musik dangdut sudah pasti memiliki kecintaan terhadap pertunjukkan musik dangdut. Mayoritas penonton pertunjukkan musik dangdut adalah kaum lakilaki baik remaja maupun orang tua. Meskipun penonton dari kalangan orang tua terbilang minoritas di sekitar wilayah Desa Banjarsawah Kecamatan Tegalsiwalan, namun mereka tetap menikmati pertunjukkan musik yang banyak dihiasi penyanyi dengan pakaian seksi ini.

Setiap penyanyi dangdut yang berada di Desa Banjarsawah ini memiliki ciri khas tersendiri agar mampu menarik perhatian penonton. Tidak berbeda dengan penyanyi dangdut kelas nasional seperti Inul Daratista, Dewi Persik, Zaskia Gotik, dan yang lainnya. Selain pakaian seksi yang ditampilkan dan didukung dengan goyangan khas. Penyanyi dangdut di Desa Banjarsawah juga memiliki ciri khasi dari caranya berkomunikasi dengan para penonton yang datang. 
"penyanyi itu tidak hanya mengandalkan penampilan saja, tetapi mampu bersikap ramah dan sering menyapa penoton seperti 'mau digoyang tidak' atau sekadar menanyakan kabar mereka".(ayu)

Kutipan wawancara berbahasa madura yang telah penulis terjemahkan tersebut, disampaikan oleh Ayu. Kutipan tersebut menunjukkan bahwa menjadi penyanyi dangdut harus bersikap ramah dan sering menyapa penonton yang datang. Sehingga, semakin senang penonton yang datang, maka akan semakin banyak saweran yang akan didapatkan oleh para penyanyi dangdut. Terlebih penyanyi dangdut yang juga berprofesi sebagai pemandu lagu, mereka akan menampakkan diri mereka secara lebih centil dan genit terhadap pelanggannya sehingga saweran yang didapatkan akan semakin banyak, bahkan lebih banyak dari bayaran yang didapatkan dari pemilik hajat atau tempat karaoke.

Penyanyi dangdut yang ada di Desa Banjarsawah ini memiliki ciri khas penggunaan bahasa madura ketika berkomunikasi dengan penonton yang datang. Hal tersebut menunjukkan sebuah bentuk pendekatan sendiri oleh penyanyi terhadap penonton, mengingat mayoritas penonton pertunjukkan musik dangdut merupakan keturunan suku madura.

"saya dalam menyanyi sering menggunakan bahasa Madura. Selain itu, saya dikenal

pula dengan goyangan jari” (Aulia)

Bentuk komunikasi yang dilakukan oleh para penyanyi dangdut tersebut bukan hanya berupa kata-kata, melainkan juga komunikasi dalam bentuk gerakan seperti lirikan mata, jari, dan gerakan tubuh yang lain. Gerakan-gerakan tersebut merupakan bentuk usaha oleh penyanyi dangdut agar penonton lebih senang dan memberikan saweran tambahan. Setiap penyanyi dangdut memiliki ciri khasnya masing-masing sebagai upaya dalam menarik perhatian penonton.

Kebiasaan yang dimiliki oleh penyanyi dangdut menunjukkan adanya persaingan dengan penyanyi dangdut yang lainnya. Penyanyi dangdut yang satu memiliki ciri khas tersendiri dalam menyapa penonton, goyangannya, maupun gaya bicara yang digunakan. Semakin unik karakteristik yang dimiliki oleh penyanyi dangdut, maka akan semakin mendapatkan respon yang tinggi dari para penonton. Habitus yang dimiliki penyanyi dangdut juga didukung oleh modal yang dimiliki. Semakin cantik penyanyi dangdut, semakin bagus pakaian yang dikenakan, dan semakin baik kemampuan menyapa dan berkomunikasi dengan penonton maka akan semakin baik pula respon yang diberikan. Semua hal yang dimiliki oleh penyanyi dangdut tersebut dijadikan sebagai bekal dalam bertarung dalam sebuah ranah pertunjukan musik dangdut. Maka, tidak heran apabila terdapat penyanyi dangdut yang kemudian sepi job atau panggilan bernyanyi dibandingkan penyanyi dangdut yang lainnya.

Penyanyi dangdut lokal harus mampu memberikan penampilan yang terbaik. Menurut salah satu penonton, penyanyi tidak hanya bernyanyi saja melainkan mampu menyapa penonton dan bersikap ramah. Selain itu, penyanyi dangdut juga harus sering menanyakan lagu apa yang ingin didengar oleh penonton. Dengan begitu penonton lebih merasa terhibur dan terkesan terhadap penyanyi dangdut karena menyanyikan apa yang diinginkan penonton. Maka, saweran yang diberikan oleh penonton pun juga semakin tinggi. Mayoritas masyarakat Desa Banjarsawah menghendaki agar penyanyi dangdut menyanyikan lagu-lagu berbahasa Madura. Namun, hal tersebut merupakan permintaan dari masyarakat yang berada pada usia dewasa ke tua. Berbeda dengan masyarakat yang masih berusia muda atau remaja, lebih menghendaki agar penyanyi dangdut menyanyikan lagu-lagu yang sedang viral saat itu. Sehingga, timbul persaingan antara penonton muda dengan penonton tua dalam memberikan saweran.

Selain itu, segmentasi penonton musik dangdut juga diklasifikasikan oleh Michael H. B Raditya tahun 2017, yaitu Penonton Joged, lebih menikmati joged dan musik ketimbang lirik; Penonton Multimedia, lebih menikmati tubuh penyanyi ketimbang genre musik Dangdut; PenontonDiam, lebih menikmati interaksi penyanyi, musik, terkadang lirik. Terlebih saya pernah 
melihatpenonton jenis ini turut bernyanyi; Penjoged, lebih menikmati musik ketimbang lirik ataupunpenyanyi sekalipun; Namun terdapat pola lainnya, yakni: penonton yang menikmati lirik dan musik,terlihat dengan hafalnya penonton. Penonton jenis ini adalah penonton aktif, karena ia turutmelakukan pelbagai upaya, seperti mendengarkan musik MP3, dan sebagainya(Raditya, 2017).

\subsection{Konflik yang Dialami PenyanyiDangdut}

Kehidupan penyanyi dangdut juga tidak terlepas dari yang namanya konflik. Konflik terjadi baik antar sesama penyanyi dangdut, maupun dengan lingkungan kehidupan keseharian mereka. Konflik antar penyanyi dangdut dapat terjadi mengingat mereka saling bersaing memperebutkan perhatian penonton supaya memberikan saweran yang lebih banyak. Sehingga, tidak jarang hal tersebut kemudian menimbulkan kecemburuan di antara mereka. Selain itu, mengenai paras yang cantik dan pakaian yang dikenakan juga tidak jarang menjadi pemicu timbulnya konflik di antara penyanyi dangdut karena rasa iri yang muncul. Pentas pertunjukkan musik dangdut yang melibatkan beberapa komponen seperti pemukul musik, penyanyi, MC, pemilih hajat, hingga penonton tersebut menambah deretan konflik yang ada. Konflik dilatarbelakangi adanya cinta segitiga diantara pegiat seni tersebut. Seperti pemain musik yang terlibat cinta segitiga dengan dua penyanyi dangdut. Bukan hanya itu, konflik juga terjadi ketika pemain musik menghubungi penyanyi dangdut untuk diajak pentas, sedangkan teman penyanyi dangdut yang lain tidak dihubungi untuk diajak pentas. Maka, akan timbul perselisihan pula.

Konflik dapat terjadi selama masih ditemukan perbedaan. Perbedaan tersebut meliputi ras, suku, agama, budaya, aliran politik, serta tujuan kehidupannya (Wirawan, 2010). Perbedaan tersebutlah yang menyebabkan adanya konflik penyanyi dangdut di Desa Banjarsawah dengan lingkungan keluarga dan tempat tinggal mereka. Perbedaan yang paling mencolok adalah dari tujuan hidup. Penyanyi dangdut memiliki tujuan hidup untuk meningkatkan perekonomian mereka, namun masyarakat lain menganggap perilaku penyanyi dangdut tidak sesuai dengan tujuan hidup mereka yakni mencari nafkah melalui pekerjaan yang dianggap lebih baik. Penyanyi dangdut di desa ini sering merasa dikucilkan oleh lingkungan sekitar mereka. Penyanyi dangdut juga sering dianggap sebelah mata terlebih yang berjenis kelamin perempuan. Para penyanyi dangdut perempuan seringkali dicap sebagai penggoda suami orang, dan penjual keseksian semata. Meskipun sebenarnya, beberapa penyanyi dangdut lebih mengutamakan kualitas suara dibandingkan keseksian mereka.

Menurut pemaparan Firda yang merupakan penyanyi dangdut di Desa Banjarsawah, disampaikan bahwa dirinya sering dikucilkan karena pekerjaannya sebagai penyanyi dangdut dianggap hanya menjual keseksian semata ditambah goyangan yang erotis. Keberadaanpenyanyi dangdut dengan goyangan erotis sudahmuncul sejak dekade 1970-an, tetapi kala itu hanya terbuka untuk kalangan dewasa belaka(Setiawan, 2019).Menurut masyarakat umum, mereka belum bisa menerima apabila remaja yang masih berstatus pelajar memiliki pekerjaan sebagai penyanyi karena dianggap kurang baik dan tidak mencerminkan identitas pelajar. Hal tersebut kemudian membuat para penyanyi dangdut merasa minder. Belum lagi, ketika para penyanyi dangdut mendapatkan label penggoda laki-laki. Padahal tindakan yang dilakukan para penyanyi dangdut tersebut hanyalah sebuah profesionalitas semata di atas panggung. Sebagai seorang biduan dangdut koplo dituntut untuk dapat bersikap profesional di atas panggung yang seringkali mengakibatkan masyarakat memiliki anggapan miring terhadap profesi seorang biduan (Hidayaningrum, 2017). 


\subsection{Perlakuan Konflik dan Komunikasi Penyelesaiannya}

Cemooh tidak hanya didapatkan oleh para penyanyi dangdut. Melainkan juga para orang tua dari penyanyi dangdut. Banyak orang tua penyanyi dangdut sering mendapatkan omongan yang menyakitkan, seperti orang tua yang tidak mampu mendidik anaknya terlebih mengizinkan anaknya yang masih berstatus pelajar bekerja dengan jalan menampilkan keseksian mereka. Oleh karena itu, para penyanyi dangdut sering memperbaiki komunikasi mereka baik dengan orang tua maupun dengan lingkungan sekitar. Sebab, komunikasi merupakan hal yang efektif dalam menangani konflik semacam ini. Menurut teori yang dikemukakan oleh Alan Sillar (Irawan dalam Besari, 2016), terdapat beberapa resolusi dalam menangani konflik, diantaranya:

- Avoidance behaviors, merupakan upaya menangani konflik dengan perilakumenghindar atau menghindari komunikasi secara langsung, seperti menjauh saatbertemu.

- Competitive behaviors, merupakan resolusi konflik dengan melibatkan pesan negatifatau melampiaskan amarah dengan kata-kata kotor.

- Cooperative behaviors, merupakan upaya penanganan konflik melalui komunikasiyang lebih terbuka dan positif.

Dari ketiga upaya penyelesaian konflik tersebut, mayortas pelaku konflik yang dalam hal ini adalah penyanyi dangdut dan lingkungan sekitarnya, memilih menggunakan resoluis cooperative behaviours yakni menggunakan komunikasi yang lebih terbuka dan positif. Para penyanyi dangdut berusaha untuk membicarakan dengan positif terhadap mereka yang sering menggunjing para penyanyi dangdut atau orang tua mereka. Namun, hal tersebut dilakukan ketika dirasa perlakuan orang lain sudah melebihi batas wajar. Gunjingan pertama akan diabaikan oleh penyanyi dangdut atau avoidance behaviors, namun apabila hal tersebut dilakukan secara berulang. Maka, penyanyi dangdut akan memilih untuk membicarakan hal tersebut melalui komunikasi yang positif. Sangat jarang ditemui penyanyi dangdut di Desa Banjarsawah yang melampiaskan gunjingan yang mereka terima dengan jalan berkata-kata kotor.

Meskipun begitu, ditemukan pula penyanyi dangdut yang beranggapan bawa dirinya hanya dipandang buruk bagi keluarga maupun lingkungannya. Ia cenderung merasa tidak disenangi orang lain, dirinya merasa tidak diperhatikan orang lain. Karena itulah ia bereaksi pada orang lain sebagai musuh, sehingga tidak dapat melahirkan kehangatan dan keakrabatan persahabatan. Ia tidak akan mempersalahkan dirinya, tetapi akan menganggap dirinya sebagai korban dari sistem yang kurang baik. Hal tersebut membuat penyanyi dangdut lebih tertutup karena mereka merasa bahwa pekerjaan yang mereka lakuakan tidak dihargai di lingkungan keluarga bahkan lingkungan masyarakat

\section{Kesimpulan}

Profesi penyanyi dangdut banyak mendapatkan pandangan buruk baik dari keluarga maupun lingkungan tempat tinggal. Penyanyi dangdut cenderung tidak disenangi oleh orang lain dan merasa tidak dipedulikan. Oleh karena itu, beberapa penyanyi dangdut memilih untuk membalas perbuatan tersebut dengan jalan menjadi musuh, berusaha berkomunikasi dengan baik, atau mengabaikan pandangan negatif orang lain. Sehingga, kehangatan dan keakraban persahabatan maupun interaksi antar tetangga kurang terjalin. Meskipun begitu, penyanyi dangdut di Desa Banjarsawah tetap menjalankan profesi mereka dengan keunikan mereka. Sebab, yang menjadi perhatian para penyanyi dangdut adalah pada kepuasan penonton dan saweran yang diberikan. Melalui cara berpakaian, ciri khas goyangan, dan keramah-tamahan para penyanyi dangdut, mereka dapat mendapatkan saweran yang banyak.

Persepsi negatif yang didapatkan penyanyi dangdut sehingga menimbulkan konflik tidak hanya terjadi antara penyanyi dangdut dengan masyarakat luas. Namun, konflik juga terjadi antar penyanyi dangdut berkat kecemburuan sosial. Semua konflik yang dialami para penyanyi 
dangdut, baik antar penyanyi dangdut maupun dengan lingkuangannya coba ditanggapi dengan jalan bersikap cuek, memperbaiki pola komunikasi yang ada sehingga masyarakat bisa menerima profesi penyanyi dangdut, dan menghindar.

\section{Saran}

Menjadi penyanyi dangdut sebenarnya bukanlah profesi yang buruk selama masih dalam koridor yang benar. Pemberian label negatif terhadap profesi ini tidak seharusnya diberikan oleh masyarakat. Sebab, label negatif yang diberikan kepada seseorang akan membuat seseorang melakukan labelling tersebut meskipun sebelumnya tidak melakukan seperti apa yang dikatakan. Tidak seharusnya masyarakat mencemooh dan memfitnah penyanyi dangdut. Begitupula penyanyi dangdut tidak seharusnya melanggar norma untuk menaikan bayaran yang mereka dapatkan.

\section{DaftarPustaka}

Besari, A. N. (2016). Konsep Diri Penyanyi Dangdut Lokal Perempuan. Semarang: Universitas Diponegoro.

Fitriya, A., \& Dwiningtyas, H. (2017). Hubungan Kuasa Komunikasi Panggung Penyanyi Dangdut. $6(1)$. online/article/view/19034/18092

Haryono, S. (2002). Dangdut dan Eksploitasi Seks Perempuan.3(2). https://doi.org/10.15294/harmonia.v3i2.688

Hidayaningrum, V.(2017). Biduan Dangdut Koplo: Kajian Relasi Kuasa dan Seksualitas Penyanyi Dangdut di Bandar Lampung [Skripsi, Universitas Lampung]. http://digilib.unila.ac.id/28755/

Ilyas. (2016). Pendidikan Karakter Melalui Homeshooling.2(1). https://journal.unnes.ac.id/nju/index.php/jne

Moleong, L. J. (2016). Metodologi Penelitian Kualitatf. Bandung: RemajaRosdaKarya.

Raditya, M. H. B. (2017). Dangdut Koplo: Memahami Perkembangan Hingga Pelarangan. 1(1). https://jsbn.ub.ac.id/index.php/sbn/article/download/2/2

Setiawan, A. R. (2019). Tak Melayang Dipuji, TakTumbang Dicaci: Kajian Biografi Oza Kioza. 1(1). https://jsbn.ub.ac.id/index.php/sbn/article/viewFile/2/2

Sulistyaningtyas, U. N., \& Suharto. (2017). Model Kemasan Bentuk Penyajian Musik Dangdut Klasik Pada Grup Musik Rhomantika, Mijen, Semarang.6(2). https://journal.unnes.ac.id/sju/index.php/jsm/article/view/16124/9840

Wirawan. (2010). Konflikdan Manajemen Konflik: Teori. Aplikasi, dan Penelitian. Jakarta: Salemba Humanika. 